\title{
Improvement of cadastral information provisioning system in an administrative region
}

\author{
Kosimdjon Rakhmonov ${ }^{1}$, Mokhigul Abdurakhimova ${ }^{1, *}$ \\ ${ }^{1}$ Tashkent Institute of Irrigation and Agricultural Mechanization Engineers (TIIAME), State Cadastre \\ Department, 39 Kari Niyaziy Street, Uzbekistan
}

\begin{abstract}
Improvement of the land cadastre information system in the administrative district will make more efficient use of the land fund. More than 42,000 land users in Kibray, which is the object of the research, can quickly manage land resources through the creation of land information systems. As a result, the use of specialized software at the district level increases the quality of the specialists' work compared to traditional methods, and time consuming 3 and 5 times the amount of data transmission to consumers. The collected and regulated data will serve as the main source of the unified system of land registration in Kibray district and the creation of a special land fund and its rational distribution among land users. The method developed to compile a digital cadastre map based on an example of an administrative district is the basis for the registration of land parcel and, in turn, the land fund distribution. Information on the state of land resources is mainly collected in the State Land Cadastre. Registration of the rights to the land parcel, the main component of which is the re-registration of new land users and the existing ones, requires the most up-to-date information on the land cadastre.
\end{abstract}

Keywords. Land cadastre, land fund, land database, land records, land balance.

\section{Introduction}

In the world practice a particular attention is paid to the problems of realization of many scientific and theoretical matters on the creation of a database. Since the period of automated systems development, theoretical problems have remained as the main driving force. Despite the technological challenges in the country, including in administrative districts, there are many problems in the implementation of these systems and the implementation of land information management using land cadastre data. The process of constantly changing the land fund, the area of land categories, the number, boundaries, area, and purpose of land users and their land parcels in all administrative districts of the Republic necessitates the creation and operation of the land cadastre system. The purpose of developing land and information databases associated with maintaining the land cadastre in the district is to create a software package that allows the processing, storage, analysis, and transfer of information on a particular land user, as well as individual facilities located

*Corresponding author: mohigul_9429@mail.ru 
on land parcels. It is well known that at the district level, the process of land use management is the main source of the land cadastre database. This entails the systematic formation of information about the district land fund. While preparing the data of land cadastre, regional land resources and department of state cadastre are the main sources in the formation of land- information systems.

\section{Materials and methods}

As professors A. A. Varlamov and S. A. Galchenko described, "The Land Cadastre is one of the information resources of the state, which is a system of information reflecting the legal, natural and economic status of the land fund" [1,2]. For this reason, it was determined that detailed information on the use of district land resources would be needed if the survey did not provide sufficient data. This will give a clear impetus to the establishment and improvement of the land information system in maintaining the land cadastre of the administrative district.

Professor A.S. Chertovitsky and A.K.Bazarov have described it as "The cadastral information systems have several features that are inherent to it: the complexity of cadastral indicators, the provision of information in two types - text and graphics, capabilities and necessity of an automated system." In order to create this concept of the land cadastre information system in the administrative districts at the level of modern requirements, it is necessary to address the following issues:

- Provision of public authorities with information on land use;

- Formation of the district land balance and statistics on the status and use of land resources at the level of modern requirements

- Organization of work on registration of rights to the land parcel by all land categories;

- Achieve proper registration of documents certifying land use and ownership, longterm use of land, lease of land and private ownership of land;

- Preparation of documents for preliminary agreement on the allocation of economic facilities, withdrawal and allocation of land, entry of land into urban areas and changing the boundaries of administrative-territorial units;

- Achievement of development goals of urban and rural areas, comprehensive development of agriculture, regulation, and coordination of land and water relations;

- Improved land records and land balance and the normative value of agricultural land;

- For proper implementation of goals of compensation of losses and losses on land acquisition;

- To encourage the rational use of land resources and to determine the methods of payment for land use;

- for the development of the real estate market and mortgage and other useful purposes.

In the administrative district land-information system, a complete database of each land parcel is collected, stored, processed and communicated to the public and private consumers. Z. S. Abdullaev acknowledges that "Cadastral assessment of land resources cannot be improved without reliable and qualitative information" [3]. However, this definition does not fully explain the nature of land cadastre information. 


\section{Discussions}

In our opinion, the automated land information system in the district can be described as a set of software and hardware-based databases that enable the entry, processing, storage and retrieval of land cadastre data. The main automated database is a system that combines data with other, aggregated data within the system.

Currently, it is necessary to create a unified database for systematic collection, updating, processing, and dissemination of land cadastre data. Increasing the use of new technologies, particularly computerization and specialized electronic software, not only enhances the development of such systems but also creates many conditions and limits. In the market economy, land-related information plays an important role in the intelligent use and development of district land resources. There is a need for a transition to traditional land registration, land surveying and land surveying using software programs. $\square$ We consider it necessary to work in the district on each mass, village and community gathering in communities, on farms, and all land plots. It is required that the specialist of the land cadastre responsible for each area should submit the data on the territory to the Department of State Land Resources and the State Cadastre. One or two experts in the department should be able to enter data into a computer and complete the data production process [4, $5]$.

We consider that the main tasks in developing the land cadastre information system in the district are:

- Creation of accurate and general information about the district land fund;

- Provision of information on targeted state activities to coordinate land reform activities [6].

The district land and information base is the lower level of the geo-information system, which is the basis for systematic improvement of the land cadastre designed for the management, analysis, and reflection of information related to land real estate and property rights.

The process of creating a district land and information system requires full registration of all land parcels owned by all land users. The task of registration of land parcels is to create a district land information system to obtain a reliable and clear basis for the right to own and dispose of the land. The data of the district land cadastre information system includes the location, boundaries, cadastre number, location, results of land ownership and land valuation, privileges and restrictions, and other information related to land servitude.

Regardless of ownership, every parcel of land in the district is subject to state registration. This will guarantee the land owner's ownership of the property and will improve fair and reasonable land and real estate taxation. The district aims to create a system of automated registration, to provide users with high-quality, graphic, written, digital, and cartographic information by simplifying data acquisition, systematization, and classification of land resources. Figure 1 summarizes the automated land cadastre information system created in the district.

The scheme of functioning of the land cadastre information system, shown in the above picture, can significantly improve the efficiency and quality of the work of specialists in the establishment of the Office of the Department of Land Resources and State Cadastre. Modern tools for collecting and processing land cadastral information in the administrative district should be created based on computing and telecommunication techniques. At the same time, the technical structure of the land cadastre information system should be formed as a result of the disclosure at all stages of the system of software and hardware systems. 


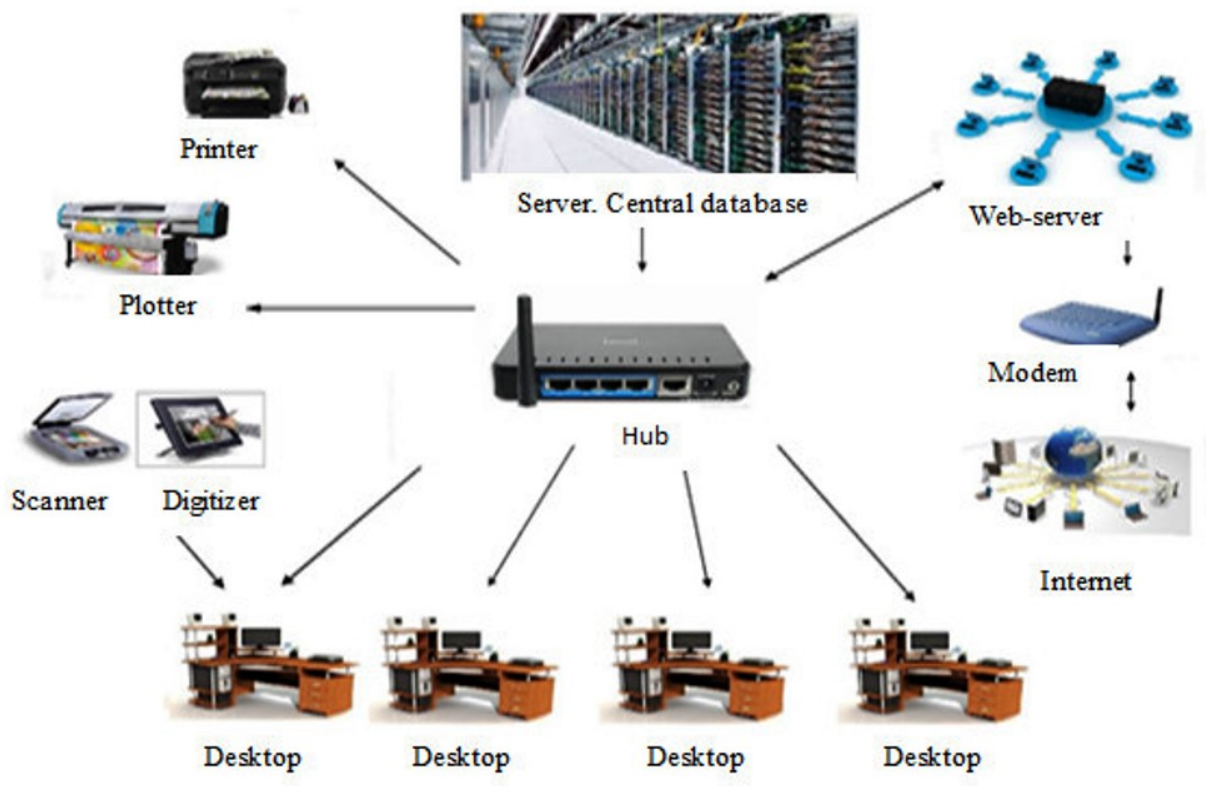

Fig.1. Scheme of operation of automated land cadastre information system of the district

Depending on the degree of opening of software and hardware complexes, the internal computing networks of various structures are one-sided, that is, the information that is distributed on the users' computers, which can be accessed from the internal network of the organization. Today, in the Kibray district of Tashkent region and other districts of the Republic, the research revealed that the above-mentioned work and use of advanced technologies were not organized at the level of modern requirements.

The total area of Kibray district is 55473 hectares, which is divided into 8 categories (as of January 1, 2019), most of which (45\%) is allocated for agricultural purposes. $51 \%$ for industry, transport, defence, communication, and other purposes, and the remaining land belongs to other categories of land. The information on land users is presented in Table 1 below.

Table1. Distribution of Kibray district land fund by land categories

\begin{tabular}{|c|l|c|c|c|}
\hline № & Categories of land fund & $\begin{array}{c}\text { Total land } \\
\text { area, } \\
\text { hectares }\end{array}$ & $\begin{array}{c}\text { Total } \\
\text { agricultural } \\
\text { land in } \\
\text { production, } \\
\text { hectares }\end{array}$ & $\begin{array}{c}\text { Other } \\
\text { lands, } \\
\text { hectares }\end{array}$ \\
\hline 1 & Agricultural lands & 25246 & 17774 & 7472 \\
\hline 2 & Lands of reserve & 271 & & 271 \\
\hline & 2.1 Chirchik River & 258 & & 258 \\
\hline & 2.2 State Reserve & 13 & & 13 \\
\hline 3 & Lands of the Forest Fund & 791 & 27 & 764 \\
\hline 4 & Lands of settlements & 176 & & 176 \\
\hline & 4.1 Kibray district center & 80 & & 80 \\
\hline & $\begin{array}{l}\text { 4.2 Salar settlement of the } \\
\text { hydroelectric power station }\end{array}$ & 64 & & 64 \\
\hline
\end{tabular}




\begin{tabular}{|c|c|c|c|c|}
\hline & 4.3 Institute of Nuclear Physics & 14 & & 14 \\
\hline & $\begin{array}{l}\text { 4.4 Yangiabad rural citizens' } \\
\text { gathering }\end{array}$ & 10 & & 10 \\
\hline & $\begin{array}{l}4.5 \text { Housing (Property and Energy } \\
\text { Company) }\end{array}$ & 8 & & 8 \\
\hline 5 & $\begin{array}{l}\text { Lands for industry, transportation, } \\
\text { communications defense, and lands } \\
\text { for other purposes }\end{array}$ & 28434 & 242 & 28192 \\
\hline $\begin{array}{l}6, \\
7\end{array}$ & $\begin{array}{l}\text { Lands for nature protection, } \\
\text { healthcare and recreational purposes } \\
\text { and Lands for historical and cultural } \\
\text { heritage }\end{array}$ & 94 & 22 & 72 \\
\hline 8 & Lands of the water fund $\square$ & 540 & & 540 \\
\hline & Total land & 55552 & 18065 & 37487 \\
\hline & $\begin{array}{l}\text { Land used outside the district } \\
\text { administrative boundaries }\end{array}$ & 79 & 76 & 3 \\
\hline & $\begin{array}{l}\text { Total land within the administrative } \\
\text { district }\end{array}$ & 55473 & 17989 & 37484 \\
\hline
\end{tabular}

Land use data in the district show that the main agricultural lands are now available for use by farmers and other land users of various specialties. Currently, there are 18 village gatherings in the district with 25246 hectares of land. Apart from that, some lands are also allocated to other businesses, institutions and organizations in the district. First and foremost, newly created or newly created land and land users, in land management and improvement of land use efficiency in the district, The following illustration shows the existing layout of arrays located in the Kibray district of the Tashkent region. molten. The current status and analysis of the registration of rights to land parcels in Kibray district are explained as follows.

It is well known that at present there are a large number of land users or other legal entities to another type of land parcel. Also, several new landowners and land users are emerging each year. It also allows these entities to register their rights to land and issue special legal documents, and to use their land to enable them to carry out their activities in a particular order. To date, over 5 million 900 thousand land plots have been distributed among land users in the Republic of Uzbekistan. In the Tashkent region and Kibray district, this figure is 410 thousand and 38 thousand respectively. To date, there are 466 major land uses in the district. It does not include household plots, trade points, and other real estate objects. Therefore, setting up a database on land is a pressing issue [7].

The number of agricultural land uses in the district is 3079 (as of January 1, 2019). Their average area is 6.9 hectares and is located on a total of 25,246 hectares. The number of land users is increasing year by year. The main reason for this is the increase in the allocation of land to farmers and dehkan farms and other types of land use. 50\% of the land fund of the district fund is owned by the Holding Company "Uzmevasabzavotuzumsanoat", which has a total area of 10334 hectares. By land weight the enterprises of the Ministry of Agriculture and Water Resources (7.7\%), subsidiary agricultural enterprises (20.6\%), agricultural research institutions and educational institutions $(14.2 \%)$, and land users of regional subordination (14.2\%), organizations of State joint-stock company of uzbek and dairy industry $(0.7 \%)$ and other agricultural enterprises $(2.5 \%)$ were allotted land plots (as of January 1, 2019).

When analyzing the legal status of land parcels in Kibray district, the extent of their use and the distribution of land resources, the following was identified:

1. There is no uniform system of land registration in the offices of the district land resources and the state cadastre; 
2. The distribution of land fund by land users by land categories is not scientificallymethodical;

3. Basis of cadastral map mapping for land parcels registration has not been studied methodically;

4. The share of agricultural land in the district is $45 \%$ of the total area and there is no proportionality in the distribution of land by agricultural specialties;

5. There are differences in the total area of land in residential areas. For example, 5110 land users are registered in the Baitkurgan village. Of these, 4,530 are land users and 580 are other land users. Of the 47 documents on land allotment is not fully completed, 16 are not drafted, and 15 are not included in the register;

6. There is no complete consistency in the documentation of land parcels in district land resources and the state cadastre services.

The process of selling the rights to a land parcel through auction also leads to an increase in registration and land allocation. As a result of real estate transactions of citizens and legal entities on the parcels of the Republic, the volume of registration and documentation is growing. During the period 2010-2018, the district carried out an average of 221 sales and re-registration of the right of inheritance [8].

\section{Conclusions}

Based on the results of the study, it is advisable to include the following in the "Land Resources and State Cadastre" section of Kibray district:

1. Centralized storage and processing of data and the creation of continuous access to the system's users;

2. Creating the necessary conditions for the processing of graphic and written information in the automated workplace by consumers;

3. Provision of primary internal data computing systems and data entry tools;

4. Availability of printing and duplication of transmitted data;

5. Communication and communications equipment should be provided to support the adopted information processing and archiving technologies.

The land information system software consists of operating systems for technical and information support, ie database management systems, as well as special application software for automating the process of processing, analyzing, storing and displaying land cadastral information. It is well-known that at present the modern development of automated information-information systems requires implementation in scientific, methodological, technological and implementation directions. Electronic program "Yeravtobank" (Landautobank) (2015), developed by the author, will provide software for creating land and information base in the district:

- processing of cadastral information on land parcels and individual objects prior to the formation of the balance sheet and ensuring the prompt transfer of information to the district land and state cadastre service;

- search and retrieval of information on cadastral numbers, contact addresses or names of users and parcels of land;

- search and selection of information about groups of land parcels by type and functional importance;

- development of electronic reporting forms for land surveying, land registration and land surveying using electronic software and transfer to district land resources and the State Land Cadastre;

- development of user manuals for software packages.

Implementation of the proposed software program in Kibray district will allow the creation of a complete database of all land parcels required by land users operating in the 
area. This system includes filling out the required tables, forms, report forms, and classifiers. This allows you to divide this information into multiple archives, transmit and extract the required data using electronic forms, and analyze or print the data in the form provided by the reports. Along with the improvement of land cadastre information, provides reliable, comprehensive information on various levels of administrative and economic services dealing with land plots and real estate in the administrative district and addressing various issues of management, planning, and control of these areas. It also serves to provide. The proposed electronic land cadastre electronic program and its scientific and methodological results will improve the efficiency of the land cadastre and create quick methods for obtaining the necessary information about land parcels. We think it is advisable to use the land cadastre for improving the information supply.

\section{References}

1. A. A. Varlamov, S. A. Galchenko, Geography and Information Systems. - M.: Kolos S., 400 (2005)

2. K. Chertovitsky, A. K. Bazarov. Land cadastre. TIIM, T., 302 (2012)

3. Z. S. Abdullaev. Fundamentals of information support for evaluation of land resources. Monograph. Tashkent. Fan Publishing, 123 (2008)

4. Q. Rakhmonov, Sh. Narbaev, Z. Mukimov, Land management. Tashkent. 154 (2018)

5. A. A. Varlamov, A. V. Sevostyanov, Land Cadastre. Volume 4. Kolos, 265 (2006)

6. S. Avezbaev, S. Volkov, Economics of land management. Yangi asr avlodi, 640 (2002)

7. U. P. Umurzakov, K. R. Rakhmonov, Effectiveness of creating an Earth-database. Journal of Irrigation and melioration. No 3 (9). 52 (2017)

8. A. I. Martynenko, Yu. L. Bugaevsky, S. N. Shibalov, Fundamentals of GIS, theory and practice. Moscow, 232 (1995) 